\title{
Herpes zoster during the COVID-19 pandemic
}

\section{Półpasiec $\mathrm{w}$ dobie pandemii COVID-19}

\author{
Olga Krupa, Aleksandra Małolepsza, Anna Woźniacka \\ Department of Dermatology and Venereology, Medical University of Lodz, Lodz, Poland
}

Klinika Dermatologii i Wenerologii, Uniwersytet Medyczny, Łódź, Polska

Dermatol Rev/Przegl Dermatol 2021, 108, 385-393

DOI: https://doi.org//0.5 | |4/dr.2021. I I3 I56

\author{
CORRESPONDING AUTHOR/ \\ ADRES DO KORESPONDENCJI: \\ Olga Krupa \\ Klinika Dermatologii \\ i Wenerologii \\ Uniwersytet Medyczny \\ Łódź, Polska \\ E-mail: olgakrupa89@gmail.com
}

\begin{abstract}
Varicella-zoster virus leads to primary infection, i.e. varicella, and remains in latent form in sensory dorsal root ganglion cells. Further replication and manifestation of skin lesions characteristic for herpes zoster may occur many years later. Primary cutaneous eruptions are blisters, filled with serous content, grouped on an erythematous area, merging into larger blisters. The virus reactivates most often in elderly people, people with impaired immunity, as well as those undergoing radiotherapy or excessive exposure to UV radiation. Recently, many studies indicate a relationship between SARS-CoV-2 and reactivation of varicellazoster virus. It is suggested that skin lesions characteristic for herpes zoster can be the first sign of COVID-19, can coexist with SARS-CoV-2 infection or can appear after recovery.
\end{abstract}

Key words: Herpes zoster, COVID-19, SARS-CoV-2.

\section{STRESZCZENIE}

Wirus ospy wietrznej i półpaśca prowadzi do pierwotnej infekcji, tj. ospy wietrznej, i pozostaje w formie latentnej w komórkach zwojowych korzeni grzbietowych. Do ponownej replikacji i wysiewu zmian skórnych charakterystycznych dla półpaśca może dojść po wielu latach. Wykwitem pierwotnym w półpaścu są pęcherzyki wypełnione treścią surowiczą, zwykle zgrupowane na rumieniowej podstawie, niekiedy zlewające się $\mathrm{w}$ większe pęcherze. Do reaktywacji wirusa dochodzi najczęściej u osób w starszym wieku, z zaburzeniami funkcji układu immunologicznego, a także poddanych radioterapii lub nadmiernej ekspozycji na promieniowanie UV. W ostatnim czasie wiele badań wskazuje na związek zakażenia wirusem SARS-CoV-2 z reaktywacją wirusa ospy wietrznej i półpaśca. Sugeruje się, że zmiany skórne charakterystyczne dla półpaśca mogą być pierwszym objawem COVID-19, współistnieć z zakażeniem SARS-CoV-2 lub pojawić się po jego przechorowaniu.

Słowa kluczowe: półpasiec, COVID-19, SARS-CoV-2. 


\section{INTRODUCTION}

Herpes zoster belongs to the group of infectious diseases that occur relatively frequently. The common name of the disease - shingles - comes from the Latin word cingulum - "waist" [1]. The causative agent is human herpesvirus 3 (HHV-3), commonly called varicella-zoster virus (VZV). It is a virus that, on first contact, causes chickenpox, a symptom of which is scattered vesicular eruptions located within the skin and mucosa and accompanying general symptoms, generally not too intense [2].

After causing chickenpox disease, VZV remains latent in ganglion cells of the dorsal roots and in ganglia of cranial nerves. Latency is defined as the presence of the viral genome within the host cells with a concomitant limited level of viral DNA expression and absence of an immune response. This condition, also known as "carrier state", is reversible, but it may persist for many years $[2,3]$.

Presence of IgG antibodies directed against varicella virus confirms the past infection and indicates acquisition of immunity. Over the years, concentration of antibodies decreases. Repeated viral replication and dissemination of skin lesions characteristic for shingles can occur after many years. When cellular immunity becomes reduced, the virus may reactivate. In the spinal ganglion, cranial nerve ganglia, and posterior horns of the spinal cord, the virus begins to multiply rapidly and travels from ganglions, through the nerve tissue and sensory nerves to respective area of the skin. Lesions usually occupy one dermatome, i.e., the skin area innervated by a single sensory nerve $[3,4]$. In the area of the nerves supplying these dermatomes, inflammation, fibrosis and demyelination occur [4].

\section{CLINICAL PRESENTATION}

In the course of herpes zoster, skin eruptions are limited and unilateral, which probably depends on the immunity resulting from previous chickenpox. It is rare for the vesicles to occupy 2 or more dermatomes (zoster duplex, zoster multiplex). Generalized skin lesions (zoster generalisatus) are the rarest, constituting $2 \%$ of cases $[5,6]$ (fig. 1 ). In case of chickenpox, however, localized vesicles are more superficial and inflammation of the surrounding skin is much less intense. Disseminated herpes zoster is associated with a more severe and longer course and coexisting inflammatory organ lesions located in lungs, the liver, kidneys or brainstem $[6,7]$. The risk of death is $5-15 \%$ and the most common cause is pneumonia [7].

Herpes zoster patients usually complain of a sudden onset of pain and/or a feeling of discomfort, preceding the appearance of skin lesions. Pain in

\section{WPROWADZENIE}

Półpasiec (herpes zoster) należy do grupy relatywnie często występujących chorób zakaźnych. Nazwa pochodzi od łacińskiego słowa cingulum - „pas" [1]. Czynnikiem wywołującym jest human herpesvirus 3 (HHV-3), zwyczajowo zwany varicella-zoster virus (VZV). Jest to wirus, który przy pierwszym kontakcie powoduje ospę wietrzną; jej objawem są rozsiane wykwity pęcherzykowe zlokalizowane w obrębie skóry i błony śluzowej oraz towarzyszące, na ogół niezbyt nasilone, objawy ogólne [2].

Po przechorowaniu ospy wietrznej VZV pozostaje $\mathrm{w}$ formie latentnej $\mathrm{w}$ komórkach zwojowych korzeni grzbietowych oraz w zwojach nerwów czaszkowych. Latencja określana jest jako obecność genomu wirusa w obrębie komórek gospodarza przy jednoczesnym ograniczonym poziomie ekspresji wirusowego DNA i braku odpowiedzi immunologicznej. Stan ten, zwany również nosicielstwem, jest odwracalny; może jednak utrzymywać się przez wiele lat $[2,3]$.

Obecność przeciwciał IgG skierowanych przeciwko wirusowi ospy wietrznej potwierdza przebyte zakażenie i świadczy o nabyciu odporności. Z biegiem lat stężenie przeciwciał się zmniejsza. Do ponownej replikacji wirusów i wysiewu zmian skórnych charakterystycznych dla półpaśca może dojść po wielu latach. W przypadku obniżenia odporności komórkowej wirus się uaktywnia. W zwoju rdzeniowym, zwojach nerwów czaszkowych i rogach tylnych rdzenia kręgowego wirus zaczyna gwałtownie się namnażać i przemieszcza się ze zwoju nerwowego przez tkankę nerwową i nerwy czuciowe do odpowiedniego obszaru skóry. Zmiany zajmują najczęściej jeden dermatom, czyli rejon skóry unerwiany przez jeden nerw czuciowy [3, 4]. W obszarze nerwów zaopatrujących te dermatomy dochodzi do powstania stanu zapalnego, włóknienia i demielinizacji [4].

\section{OBRAZ KLINICZNY}

W przebiegu półpaśca zmiany skórne są ograniczone i jednostronne, co zależy prawdopodobnie od odporności powstałej w wyniku przebytej wcześniej ospy wietrznej. Rzadko zdarza się, że pęcherzyki zajmują 2 lub więcej dermatomów (zoster duplex, zoster multiplex). Uogólnione zmiany skórne (zoster generalisatus) występują najrzadziej, w 2\% przypadków [5, 6] (ryc. 1). W przypadku ospy wietrznej pęcherzyki zlokalizowane są jednak bardziej powierzchownie, a stan zapalny otaczającej skóry znacznie mniej nasilony. Półpasiec rozsiany wiąże się z cięższym i dłuższym przebiegiem, a także wspólistniejącymi zmianami narządowymi o charakterze zapalnym, które zlokalizowane są w płucach, wątrobie, nerkach lub pniu mózgu [6, 7]. Ryzyko 


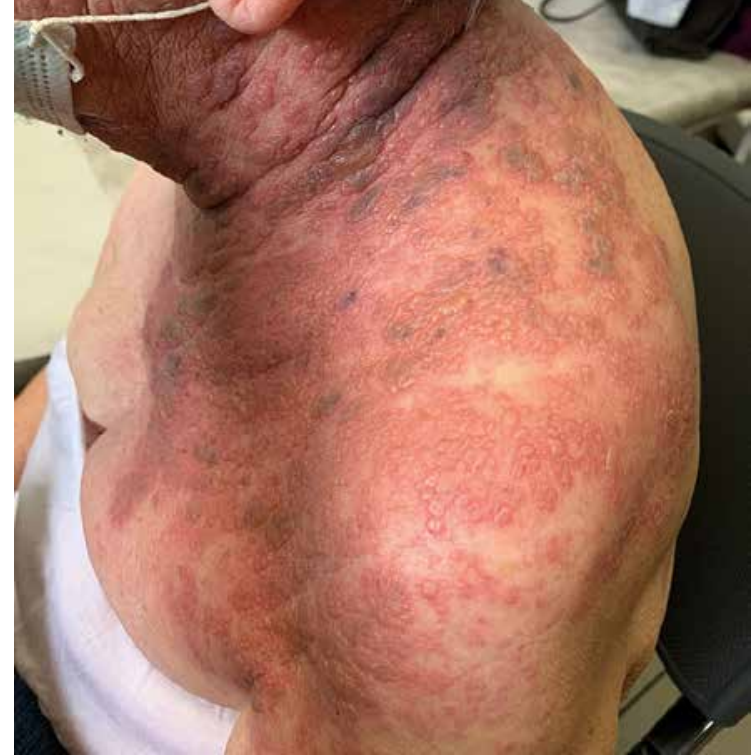

Figure I. Disseminated herpes zoster

Rycina I. Półpasiec rozsiany

the prodromal period may be misdiagnosed as renal colic, hepatic colic, colic in the course of cholelithiasis, myocardial infarction, pleuritis, toothache, glaucoma or appendicitis [7].

The primary lesion in the herpes zoster is a serous vesicle with a durable cover and a diameter of 2 to $5 \mathrm{~mm}$. Vesicles are usually grouped on an erythematous base, sometimes coalescing to form larger blisters. Between them there may be fragments of unchanged skin. In the following days, the contents of the vesicles become cloudy, sometimes lesions become hemorrhagic, and in the final stage they become crusted or superficial erosions are visible. Scabs last for 2 to 4 weeks and may disappear leaving scars or discoloration [6, 7].

Although common Polish name of the disease suggests that typical lesions take "half a waist", the most common location, especially in the elderly, is the face. Eruptions are located within the areas innervated by the branches of the trigeminal nerve, the first of which is the ophthalmic nerve (V1) (fig. 2). It is the sensory nerve that supplies the upper face. The maxillary nerve (V2) is also a sensory nerve and innervates the skin between the lower eyelid and the mouth line. The mandibular nerve (V3) is a sensorimotor nerve, it sensory innervates the skin below the mouth and temples [6].

Less frequently observed forms of herpes zoster include: gangrenous (zoster gangraenosus), haemorrhagic (zoster haemorrhagicus), ocular (zoster ophthalmicus), otic (zoster oticus). Moreover, due to the localization, oral zoster, cranial zoster, perineal zoster and herpes zoster with no skin lesions - zoster sine herpete, are diagnosed $[4,6,7]$. In children herpes zoster

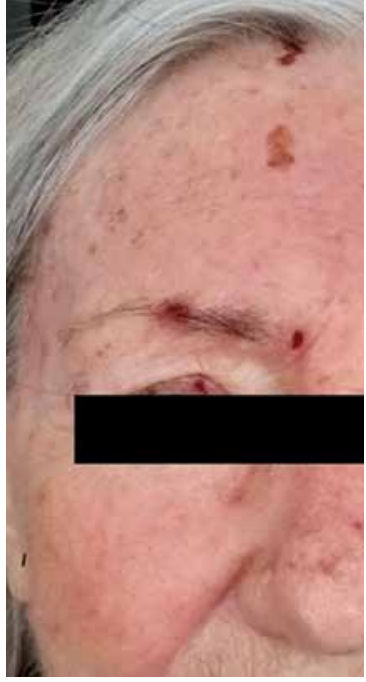

Figure 2. 8I-year-old female patient with herpes zoster ophthalmicus in the healing phase of erosions and scabs. Visible symptom of Hutchinson involving the inflammatory process of the nasociliary nerve and manifested by the presence of vesicular lesions on the bridge of the nose. In these cases, there is an increased likelihood of inflammation also in the cornea of the eye

Rycina 2. Pacjentka 8 I -letnia z postacią oczną półpaśca w fazie gojenia nadżerek i strupów. Widoczny objaw Hutchinsona polegający na zajęciu procesem zapalnym nerwu nosowo-rzęskowego, objawiający się obecnością zmian pęcherzykowych na grzbiecie nosa. W tych przypadkach istnieje zwiększone prawdopodobieństwo wystąpienia zapalenia również w obrębie rogówki oka

zgonu wynosi 5-15\%, a najczęstszą przyczyną jest zapalenie płuc [7].

Chorzy na półpasiec skarżą się zwykle na nagły początek dolegliwości bólowych i/lub poczucie dyskomfortu poprzedzające wysiew zmian skórnych. Ból w okresie prodromalnym może być mylnie rozpoznawany jako kolka nerkowa, wątrobowa, kolka w przebiegu kamicy żółciowej, zawał mięśnia sercowego, zapalenie opłucnej, ból zęba, jaskra lub zapalenie wyrostka robaczkowego [7].

Wykwitem pierwotnym w półpaścu jest surowiczy pęcherzyk o trwałej pokrywie i średnicy od 2 do $5 \mathrm{~mm}$. Pęcherzyki są zwykle zgrupowane na rumieniowej podstawie, niekiedy zlewają się, tworząc większe pęcherze. Pomiędzy nimi mogą występować fragmenty skóry niezmienionej. W czasie kolejnych dni treść pęcherzyków mętnieje, niekiedy zmiany stają się krwotoczne, a w końcowym etapie pokrywają się strupem lub widoczne są powierzchowne nadżerki. Strupy utrzymują się od 2 do 4 tygodni, a mogą ustępować z pozostawieniem blizn lub przebarwień $[6,7]$.

Najczęstszym umiejscowieniem, zwłaszcza u osób starszych, jest twarz. Wykwity lokalizują się w obrębie miejsc unerwianych przez gałązki nerwu trójdzielnego, z których pierwszą jest nerw oczny (V1) (ryc. 2). Jest to nerw czuciowy zaopatrujący górną część twarzy. Nerw szczękowy (V2) jest również nerwem czuciowym i unerwia skórę pomiędzy powieką dolną a linią ust. 
is rare. In infants, it may result from maternal chickenpox during pregnancy [3].

Skin lesions are accompanied by various severity of pain, which may also persist after their disappearance. Comorbid pain usually intensifies in the evening and at night [4]. There are several types of pain in the course of the disease:

- spontaneous, continuous, unrelated to stimulus (stinging often associated with a greater likelihood of postherpetic neuralgia),

- spontaneous, occurring periodically, not related to the stimulus, e.g., pain in the prodromal period,

- allodynia - pain sensations in response to a stimulus that had not caused pain before,

- paresthesia, dysesthesia - having the character of burning pain, neuropathic pain - burning pain $[4,6]$.

\section{COMPLICATIONS}

Postherpetic neuralgia is considered to be the most common and most burdensome complication of the disease. It is diagnosed in the case of pain persisting despite disappearance of skin lesions. It is caused by post-inflammatory nerve damage and disturbed nerve excitability in ganglia and the spinal cord $[4,7]$.

Incidence of postherpetic neuralgia increases with the patient's age and is assessed differently depending on the studied population, and ranges from $15 \%$ to $30 \%[4,6]$. Postherpetic neuralgia sometimes resolves spontaneously. However, it may persist for a long time, i.e., from several months to several years [4]. It can cause anxiety disorders, weight loss, insomnia, social isolation, depression, and even lead to suicide [7-9].

Other complications of herpes zoster include secondary bacterial superinfections (Staphylococcus aureus, Streptococcus pyogenes) [7], and necrotizing fasciitis [3]. A complication of ocular herpes zoster is paralysis of oculomotor muscles or keratitis, which may lead to blindness. Inflammation of the vestibulocochlear nerve may lead to impaired hearing or, less commonly, permanent hearing loss. Less frequent are facial and trigeminal nerve palsy [6, 7], as well as acute or chronic encephalitis, aseptic meningitis, myelitis, multi-radicular inflammation, retinitis, Guillain-Barré syndrome and hemiparesis [7].

Herpes zoster increases the risk of stroke, especially in the first month after the patient's skin has cleared, but also up to a year afterwards. It can manifest as an ischemic stroke, hemorrhagic stroke or transient ischemic attacks (TIA). The risk increases in the case of V1 involvement of the trigeminal nerve $[9,10]$. The underlying cause is believed to be an inflammation caused by VZV, which spreads transaxonally into large arteries of the brain from vessels pass-
Nerw żuchwowy (V3) jest nerwem czuciowo-ruchowym, unerwia czuciowo skórę poniżej ust i skroni [6].

Do rzadziej obserwowanych postaci półpaśca należą: postać zgorzelinowa (zoster gangraenosus), krwotoczna (zoster haemorrhagicus), oczna (zoster ophthalmicus), uszna (zoster oticus). Ponadto, ze względu na lokalizację, rozpoznaje się półpasiec jamy ustnej (oral zoster), czaszkowy (cranial zoster), krocza (zoster perineal) i półpasiec bez zmian skórnych - zoster sine herpete $[4,6,7]$. Półpasiec u dzieci występuje rzadko. U niemowląt może być wynikiem przebycia przez matkę w ciąży ospy wietrznej [3].

Zmianom skórnym towarzyszą różnie nasilone dolegliwości bólowe, które utrzymywać się mogą również po ich ustąpieniu. Współistniejący ból najczęściej nasila się wieczorem i w nocy [4]. W przebiegu choroby można wyróżnić kilka rodzajów bólu: spontaniczny, ciągły, bez związku z bodźcem, piekący, pulsujący lub ostry - piekący, często związany z większym prawdopodobieństwem wystąpienia neuralgii popółpaścowej; spontaniczny, występujący okresowo, bez związku z bodźcem, np. ból w okresie prodromalnym; allodynia - odczucia bólowe w odpowiedzi na bodziec, który wcześniej nie wywoływał bólu; parestezje w postaci uczucia mrowienia lub świądu, dyzestezje i ból neuropatyczny [4, 6].

\section{POWIKŁANIA}

Neuralgia popółpaścowa uważana jest za najczęściej występujące i najbardziej uciążliwe powikłanie choroby. Rozpoznawana jest w przypadku utrzymywania się bólu, pomimo ustąpienia zmian skórnych. Jej przyczyną jest pozapalne uszkodzenia nerwów i zaburzenia pobudliwości nerwów w zwojach i rdzeniu kręgowym [4, 7].

Częstość występowania neuralgii popółpaścowej wzrasta $\mathrm{z}$ wiekiem pacjenta i jest różnie oceniana w zależności od badanej populacji i wynosi od 15\% do 30\% $[4,6]$. Neuralgia popółpaścowa niekiedy ustępuje samoistnie, może jednak utrzymywać się długo, tj. od kilku miesięcy do kilku lat [4]. Może być przyczyną zaburzeń lękowych, utraty masy ciała, bezsenności, izolacji społecznej, depresji, a nawet prowadzić do samobójstwa [7-9].

Do innych powikłań półpaśca należą wtórne nadkażenia bakteryjne (Staphylococcus aureus, Streptococcus pyogenes) [7], a także martwicze zapalenie powięzi [3]. Powikłaniem półpaśca ocznego jest porażenie mięśni okoruchowych lub zapalenie rogówki, które może być przyczyną utraty wzroku. W przypadku zapalenia nerwu przedsionkowo-ślimakowego może się rozwinąć niedosłuch lub, rzadziej, trwała utrata słuchu. Rzadziej obserwuje się porażenie nerwu twarzowego i trójdzielnego [6, 7], a także ostre lub przewlekłe zapalenie mózgu, aseptyczne zapalenie opon mózgowo-rdzeniowych, za- 
ing through meninges innervated by the trigeminal nerve. Necrotizing arteritis can cause thrombosis or bleeding. VZV infection may also cause development of brain aneurysms, thrombosis of the cerebral veins, subarachnoid or intracerebral hemorrhage $[2,9]$.

\section{CHICKENPOX AND SHINGLES}

Herpes zoster can occur after recovering from chickenpox or after vaccination against chickenpox, regardless of the time since infection or vaccination. Severity of skin lesions in the course of herpes zoster is not related to the severity of chickenpox in the past $[3,8]$. However, it has been shown that shingles is more frequent and usually more severe after suffering from chickenpox than in the case of VZV reactivation following vaccination against varicella. A lower frequency of herpes zoster episodes after vaccination against chickenpox was also observed, even in immunocompromised children $[3,8]$.

\section{EPIDEMIOLOGY}

Factors that may affect the risk of reactivation of infection are: age (more often in people in the $6^{\text {th }}$ decade of life or older), disorders of the immune system, comorbidities (e.g., systemic lupus erythematosus, rheumatoid arthritis, ulcerative colitis, Hodgkin's disease, Crohn's disease, tuberculosis, syphilis, AIDS), radiotherapy, excessive exposure to UV radiation, stress, injuries and accompanying infections [5].

Usually, reactivation of VZV occurs once in a lifetime, however, in about $5 \%$ of people suffering from the disease, the changes recur [3]. Recurrent and disseminated shingles are an indication for the extension of diagnosis towards coexistence of clinically significant immune disorders and exclusion of concomitant diseases, especially neoplastic.

Both the neurotrophic VZV and SARS-CoV-2 have an affinity for the nervous system. These viruses increase the risk of stroke, which is probably associated with increased inflammation in blood vessels. Although so far it is difficult to determine the pathogenetic relationship between COVID-19 and herpes zoster, the increase in the coexistence of both diseases observed in the world, especially in young, immunocompetent people, prompts taking a thorough epidemiological history and performing additional diagnostic tests in patients with shingles, even in the absence of symptoms of SARS-CoV-2 infection $[9,10]$.

\section{PREVENTION}

The latest data in the literature present opinions on the need to consider the usefulness of vaccination palenie rdzenia kręgowego, zapalenie wielokorzeniowe, zapalenie siatkówki, zespół Guillaina-Barrégo i niedowład połowiczy [7].

Zachorowanie na półpasiec zwiększa ryzyko udaru mózgu, szczególnie $\mathrm{w}$ pierwszym miesiącu, ale nawet do roku od ustąpienia zmian skórnych. Może manifestować się jako udar niedokrwienny, krwotoczny lub przemijające napady niedokrwienne (transient ischemic attacks - TIA). Ryzyko to wzrasta w przypadku zajęcia V1 nerwu trójdzielnego [9, 10]. Przyczyn upatruje się w stanie zapalnym spowodowanym VZV, który przenosi się transaksonalnie do dużych tętnic mózgu z naczyń przechodzących przez opony mózgowe unerwiane przez nerw trójdzielny. Martwicze zapalenie tętnic może być przyczyną zakrzepicy albo krwawienia. Infekcja VZV może być również przyczyną rozwoju tętniaków mózgu, zakrzepicy żył mózgowych, krwotoku podpajęczynówkowego lub śródmózgowego [2,9].

\section{OSPA WIETRZNA A PÓŁPASIEC}

Zachorowanie na półpasiec może wystąpić po przechorowaniu ospy wietrznej lub po szczepieniu przeciwko ospie wietrznej, niezależnie od czasu, jaki upłynął od zakażenia lub szczepienia. Nasilenie zmian skórnych w przebiegu półpaśca nie ma związku z ciężkością przebiegu ospy wietrznej w przeszłości [3, 8]. Wykazano jednak, że po przechorowaniu ospy wietrznej półpasiec występuje częściej i ma zwykle cięższy przebieg niż w przypadku reaktywacji wirusa VZV podanego w następstwie szczepienia przeciw ospie wietrznej. Obserwowano również mniejszą częstość występowania epizodów półpaśca po szczepieniu przeciwko ospie wietrznej, nawet u dzieci z upośledzoną odpornością [3, 8].

\section{EPIDEMIOLOGIA}

Czynnikami, które mogą mieć wpływ na ryzyko reaktywacji zakażenia, są: wiek (częściej u osób w 6. dekadzie życia lub starszych), zaburzenia funkcji układu immunologicznego, choroby współistniejące (np. toczeń rumieniowaty układowy, reumatoidalne zapalenie stawów, wrzodziejące zapalenie jelita grubego, choroba Hodgkina, choroba Leśniowskiego-Crohna, gruźlica, kiła, AIDS), radioterapia, nadmierna ekspozycja na promieniowanie UV, stres, urazy oraz towarzyszące infekcje [5].

Zwykle do reaktywacji VZV dochodzi raz w życiu, jednak u ok. 5\% osób chorujących zmiany występują nawrotowo [3]. Półpasiec nawrotowy oraz rozsiany są wskazaniem do poszerzenia diagnostyki w kierunku współistnienia istotnych klinicznie zaburzeń odporności i wykluczenia chorób towarzyszących, zwłaszcza nowotworowych. 
against herpes zoster, because the level of antibodies after chickenpox clearly decreases after the age of 50 . Preliminary results from a study of 2 million Americans aged 66 years and older found that vaccination against herpes zoster reduced the risk of herpes zoster (by 51\%) and post-herpetic neuralgia (by 66\%), as well as stroke (by about $16 \%$ ). This applies to both ischemic and hemorrhagic stroke [11, 12]. Currently, two vaccines against herpes zoster are registered in the USA: the older one containing live attenuated varicella zoster virus, called Zostavax, used since 2006 (in the European Union registered by the European Medicine Agency - EMA in March 2013, in Poland not available) and a newer one, adjuvanted inactivated vaccine containing recombinant varicella zoster virus proteins called Shingrix. This vaccine was registered for use in European Union countries by the EMA in March 2018. As for now, it is not available in Poland [13-15]. These live attenuated vaccines are not recommended for pregnant women, children, or patients with autoimmune diseases. Therapy with the use of biological drugs is a contraindication. The American Advisory Committee on Immunization Practices recommends administering the preparation 14 days before starting immunosuppressive treatment or one month after stopping immunosuppressive drugs. The vaccine should not be given to patients during antiviral treatment as it could inhibit replication of virus from the vaccine and reduce effectiveness of the immunization. Patients undergoing chronic antiviral therapy should discontinue treatment at least 24 hours before vaccination and should not take them until 14 days after vaccination. People on low doses of immunosuppressants can be vaccinated after consulting an immunodeficiency specialist, and a decision is made on an individual basis. Vaccination against herpes zoster should be particularly recommended to people from risk groups, especially the elderly [11]

A vaccine against chickenpox is available in Poland, which reduces the risk of developing chickenpox, and possibly also shingles in the future. It seems that it can also have a prophylactic function, reducing the risk of post-herpetic neuralgia. It is a live virus vaccine that can be used from 9 months of age, with no upper age limit. The vaccination schedule consists of two doses of vaccine given at least 6 weeks apart. It can be taken by people who have not yet had chickenpox. This vaccine is free of charge only for selected groups of children, e.g., those attending the nursery. It belongs to the group of recommended vaccinations in Poland [16].

\section{TREATMENT}

The primary goal of treating herpes zoster is to prevent development of the disease and to reduce
Zarówno neurotropowy VZV, jak i SARS-CoV-2 wykazują powinowactwo do układu nerwowego. Wirusy te przyczyniają się do zwiększenia ryzyka wystąpienia udaru, co ma prawdopodobnie związek $\mathrm{z}$ nasilonym procesem zapalnym $\mathrm{w}$ obrębie naczyń krwionośnych. Mimo że do tej pory trudno jest określić związek patogenetyczny między COVID-19 i półpaścem, to jednak obserwowany na świecie wzrost współwystępowania obu chorób, zwłaszcza u młodych, immunokompetentnych osób, skłania do przeprowadzenia $\mathrm{u}$ chorych na półpasiec skrupulatnego wywiadu epidemiologicznego i ewentualnych badań diagnostycznych, nawet w przypadku braku objawów zakażenia SARS-CoV-2 $[9,10]$.

\section{PROFILAKTYKA}

Najnowsze dane z piśmiennictwa zawierają opinie dotyczące konieczności rozważenia przydatności szczepienia przeciwko półpaścowi, ponieważ stężenie przeciwciał po przechorowaniu ospy wietrznej wyraźnie zmniejsza się po 50. roku życia. Wstępne wyniki badania przeprowadzonego w grupie 2 milionów Amerykanów w wieku 66 lat lub starszych wykazały, że szczepienie przeciw półpaścowi zmniejsza ryzyko jego wystąpienia (o 51\%) i neuralgii popółpaścowej (o 66\%), a także udaru (o ok. 16\%). Dotyczy to zarówno udaru niedokrwiennego, jak i udaru krwotocznego [11, 12]. Obecnie w USA zarejestrowane są dwie szczepionki przeciw półpaścowi: starsza zawierająca żywe osłabione wirusy ospy wietrznej i półpaśca o nazwie Zostavax, stosowana od 2006 roku (w krajach Unii Europejskiej zarejestrowana przez European Medicine Agency - EMA w marcu 2013 roku, w Polsce niedostępna) oraz nowsza szczepionka inaktywowana $\mathrm{z}$ adiuwantem, zawierająca rekombinowane białka wirusa ospy wietrznej i półpaśca o nazwie Shingrix. Szczepionka ta została zarejestrowana do stosowania w krajach Unii Europejskiej przez EMA w marcu 2018 roku. W Polsce jeszcze nie jest dostępna [13-15]. Te żywe atenuowane szczepionki nie są zalecane kobietom w ciąży, dzieciom oraz pacjentom z chorobami autoimmunologicznymi. Przeciwwskazaniem jest prowadzona terapia z użyciem leków biologicznych. Amerykański Komitet Doradczy ds. Szczepień przy Centrum Kontroli Chorób i Prewencji (CDC Advisory Committee on Immunization Practices) rekomenduje podawanie preparatu $14 \mathrm{dni}$ przed rozpoczęciem leczenia immunosupresyjnego lub miesiąc po zakończeniu przyjmowania leków immunosupresyjnych. Szczepionka nie powinna być podawana pacjentom $\mathrm{w}$ trakcie leczenia przeciwwirusowego, ponieważ może spowodować zahamowanie replikacji wirusa szczepionkowego i zmniejszyć skuteczność szczepionki. Chorzy poddawani przewlekłej terapii antywirusowej powinni przerwać leczenie co najmniej 24 godziny przed szczepieniem i przez 14 dni po szcze- 




Figure 3. Herpes zoster in a patient with a history of SARS-CoV-2 infection

Rycina 3. Półpasiec u pacjenta po przebytym zakażeniu wirusem SARS-CoV-2

the risk of severe complications, such as postherpetic neuralgia or secondary bacterial superinfections. Rapid implementation of antiviral therapy and inhibition of VZV replication is especially important in patients with impaired immune system and in cases of ophthalmic herpes zoster. In Poland, acyclovir is used in therapy at the dose of $800 \mathrm{mg} 5$ times a day for at least 6 days. Valaciclovir has also been proven to be effective. In post-herpetic neuralgia, pregabalin or gabapentin is the most commonly prescribed treatment. Moreover, in the treatment of postherpetic neuralgia, topical patches with $5 \%$ lidocaine, $8 \%$ capsaicin, EMLA cream, creams with doxepin or infiltration blocks with $1 \%$ lidocaine are used [4].

\section{SHINGLES AND COVID-19}

Clinical experience gained in the last year and numerous articles published in medical magazines indicate that reactivation of the VZV virus and the appearance of skin lesions typical for herpes zoster may be the first symptom, may coexist with SARS-CoV-2 infection, or appear after COVID-19 infection (fig. 3). COVID-19, which is an acute infectious disease accompanied by high emotional stress, may therefore be a factor triggering multiplication of the latent form of the virus [17]. COVID-19 infection has been shown to reduce the number of CD4+ T cells, CD8+ $\mathrm{T}$ cells, B cells, and NK cells. It can be suspected that SARS-CoV-2 virus directly contributes to death of lymphocytes, leading to lymphopenia, and hence to a decrease in antiviral immunity. Diagnostics for COVID-19 infection is suggested in patients with herpes zoster, even in the absence of respiratory symptoms [18]. Reports of high efficacy of COVID-19 vaccines are promising. Vaccine immunity has been pieniu. Osoby otrzymujące niskie dawki leków immunosupresyjnych mogą zostać zaszczepione, aspekt ten rozpatrywany jest indywidualnie. Szczepienie przeciwko półpaścowi powinno być szczególnie zalecane osobom z grup ryzyka, a przede wszystkim osobom starszym [11].

W Polsce dostępna jest szczepionka przeciwko ospie wietrznej, która zmniejsza ryzyko zachorowania na ospę wietrzną, a w przyszłości ewentualnie również na półpasiec. Wydaje się, że może też spełniać funkcję profilaktyczną zmniejszającą ryzyko rozwoju neuralgii popółpaścowej. Jest to szczepionka zawierająca żywe wirusy, którą można stosować od 9. miesiąca życia bez górnej granicy wiekowej. Schemat szczepienia polega na podaniu 2 dawek szczepionki w odstępie co najmniej 6 tygodni. Mogą ją przyjąć osoby, które nie przechorowały dotychczas ospy wietrznej. Szczepionka ta jest bezpłatna tylko dla wybranych grup dzieci, np. uczęszczających do żłobka. Należy do szczepień zalecanych [16].

\section{LECZENIE}

Zasadniczym celem leczenia półpaśca jest zapobieganie rozwojowi choroby i zmniejszenie ryzyka wystąpienia ciężkich powikłań, takich jak neuralgia popółpaścowa lub wtórne nadkażenia bakteryjne. Szybkie wdrożenie terapii przeciwwirusowej i zahamowanie replikacji VZV jest szczególnie ważne u pacjentów $\mathrm{z}$ upośledzonym układem odpornościowym oraz w przypadku półpaśca ocznego. W Polsce w terapii stosowany jest acyklowir w dawce $800 \mathrm{mg}$ 5 razy na dobę przez co najmniej $6 \mathrm{dni}$. Udowodnioną skuteczność ma także walacyklowir. W neuralgii popółpaścowej najczęściej zalecana jest pregabalina lub gabapentyna. Ponadto $\mathrm{w}$ leczeniu neuralgii popółpaścowej stosowane są miejscowo plastry z 5\% lidokainą, 8\% kapsaicyna, krem EMLA, kremy z doksepiną lub blokady nasiękowe z 1\% lidokainą [4].

\section{PÓŁPASIEC A COVID-19}

Uzyskane w ostatnim roku doświadczenie kliniczne i doniesienia literaturowe wskazują, że reaktywacja wirusa VZV i pojawienie się typowych dla półpaśca zmian skórnych może być pierwszym objawem, współistnieć z zakażeniem SARS-CoV-2 lub pojawić się po przechorowaniu COVID-19 (ryc. 3). COVID-19, będący ostrą chorobą infekcyjną, której towarzyszy duży stres, może być czynnikiem wyzwalającym namnażanie latentnej formy wirusa [17]. Wykazano, że infekcja COVID-19 prowadzi do zmniejszenia liczby limfocytów T CD4+, limfocytów T CD8+, limfocytów B oraz komórek NK. Można podejrzewać, że wirus SARS-CoV-2 przyczynia się bezpośrednio do śmierci komórkowej limfocytów, co prowadzi do 
suggested to be superior to that obtained naturally from SARS-CoV-2 infection. However, even if the level of antibodies after vaccination may not be sufficient to provide complete protection against the disease, it may prevent serious complications. The literature shows that the level of antibodies generated during COVID-19 infection is variable, and therefore may not provide protection against recurrence, which, apart from complications from the respiratory or nervous system, may increase the risk of herpes zoster [19].

\section{CONCLUSIONS}

Although the relationship between COVID-19 and Herpesviridae is not well understood, some reports suggest development of herpes zoster as a possible complication of SARS-CoV-2 infection. Usually, when the host's cellular immunity is lowered, the virus reactivates, which is observed in immunocompromised patients. In the course of COVID-19, there is also a decrease in cellular immunity, leading to a decrease in the number of lymphocytes, especially CD3+, CD4+, CD8+ T lymphocytes. The likely cause of VZV reactivation is reduction in the absolute number of lymphocytes, caused by SARS-CoV-2 infection [20]. COVID-19 infection may therefore increase the risk of VZV reactivation by lowering cellular immunity. Increased incidence of shingles in the population during the pandemic may also be explained by the increased psychological stress during this period [17].

\section{CONFLICT OF INTEREST}

The authors declare no conflict of interest. limfopenii, a także obniżenia odporności przeciwwirusowej. Sugeruje się diagnostykę w kierunku zakażenia COVID-19 u pacjentów z półpaścem, nawet w przypadku braku objawów ze strony układu oddechowego [18]. Obiecujące są doniesienia o dużej skuteczności szczepionek przeciwko COVID-19. Odporność poszczepienna ma przewagę nad odpornością uzyskaną w sposób naturalny w przypadku zakażenia SARS-CoV-2. Nawet jeśli poziom przeciwciał po szczepieniu może nie być wystarczający, żeby zapewnić całkowitą ochronę przed zachorowaniem, może zapobiegać poważnym powikłaniom infekcji. Z piśmiennictwa wynika, że poziom przeciwciał wytworzonych w trakcie infekcji COVID-19 jest zmienny, w związku z tym może nie zapewniać ochrony przed ponownym zachorowaniem, które poza powikłaniami ze strony układu oddechowego lub nerwowego, może zwiększać ryzyko wystąpienia półpaśca [19].

\section{WNIOSKI}

Mimo że związek COVID-19 z Herpesviridae nie jest dobrze poznany, niektóre doniesienia sugerują rozwój półpaśca jako możliwe powikłanie zakażenia SARS-CoV-2. Zwykle w przypadku obniżenia odporności komórkowej gospodarza dochodzi do reaktywacji wirusa, co obserwuje się u pacjentów z niedoborami odporności. W przebiegu COVID-19 dochodzi również do obniżenia odporności komórkowej, co prowadzi do zmniejszenia liczby limfocytów, zwłaszcza limfocytów T CD3+, CD4+, CD8+. Prawdopodobną przyczyną reaktywacji wirusa VZV jest obniżenie bezwzględnej liczby limfocytów spowodowane zakażeniem SARS-CoV-2 [20]. Infekcja COVID-19 może zwiększać ryzyko reaktywacji VZV poprzez obniżenie odporności komórkowej. Zwiększoną liczbę zachorowań na półpasiec $\mathrm{w}$ populacji $\mathrm{w}$ trakcie pandemii można także tłumaczyć zwiększonym stresem psychicznym w tym okresie [17].

\section{KONFLIKT INTERESÓW}

Autorzy nie zgłaszają konfliktu interesów.

\section{References \\ Piśmiennictwo}

1. Mohan R.P.S., Verma S., Singh U., Agarwal N.: Herpes zoster. BMJ Case Rep 2013, 1-3.

2. Dworkin R.H., Johnson R.W., Breuer J., Gnann J.W., Levin M.J., Backonja M., et al.: Recommendations for the management of herpes zoster. Clin Infect Dis 2007, 44 (Suppl 1), 1-26.

3. Leung A.K.C., Barankin B.: Herpes zoster in childhood. Open J Pediatr 2015, 5, 39-44.

4. Malec-Milewska M.: Neuralgia popółpaścowa. Medycyna Paliatywna w Praktyce 2012, 6, 28-37.

5. Oxman M.N.: Herpes zoster pathogenesis and cell-mediated immunity and immunosenescence. J Am Osteopath Assoc 2009, 109, 13-17.

6. Lautenschlager S., Stockfleth E.: Ludzkie wirusy opryszczki. [In:] Braun-Falco dermatologia. Tom I. W.H.C. Burgdorf, G. Plewig, H.H. Wolff, M. Landthaler. Wydawnictwo Czelej, Lublin, 2017, 88-92.

7. Sampathkumar P., Drage L.A., Martin D.P.: Herpes zoster (shingles) and postherpetic neuralgia. Mayo Clin Proc 2009, 84, 274-280.

8. Bujnowska-Fedak M.M., Węgierek P.: Pacjent z półpaścem w praktyce lekarza rodzinnego. Forum Med Rodzinnej 2018, 12, 107-114. 
9. John A.R., Canaday D.H.: Herpes zoster in the older adult. Infect Dis Clin North Am 2017, 31, 811-826.

10. Marra F., Ruckenstein J., Richardson K.: A meta-analysis of stroke risk following herpes zoster infection. BMC Infect Dis 2017, 17, 198.

11. Koshy E., Mengting L., Kumar H., Jianbo W.: Epidemiology, treatment and prevention of herpes zoster: a comprehensive review. Indian J Dermatol Venereol Leprol 2018, 84, 251-262.

12. Klein N.P., Bartlett J., Fireman B., Marks M.A., Hansen J., Lewis E.: Long-term effectiveness of zoster vaccine live for postherpetic neuralgia prevention. Vaccine 2019, 37, 5422-5427.

13. James S.F., Chahine E.B., Sucher A.J., Hanna C.: Shingrix: the new adjuvanted recombinant herpes zoster vaccine. Ann Pharmacother 2018, 52, 673-680.

14. Syed Y.Y.: Recombinant zoster vaccine (Shingrix ${ }^{\circledR}$ ): a review in herpes zoster. Drugs Aging 2018, 35, 1031-1040.

15. Shah R.A., Limmer A.L., Nwannunu C.E., Patel R.R., Mui U.N., Tyring S.K.: Shingrix for herpes zoster: a review. Skin Therapy Lett 2019, 24, 5-7.

16. Chiu S.S., Lau Y.L.: Review of the Varilrix varicella vaccine. Expert Rev Vaccines 2005, 4, 629-643.

17. Pona A., Jiwani R.A., Afriyie F., Labbe J., Cook P.P., Mao Y.: Herpes zoster as a potential complication of coronavirus disease 2019. Dermatol Ther 2020, 33, e13930.

18. Elsaie M.L., Youssef E.A., Nada H.A.: Herpes zoster might be an indicator for latent COVID 19 infection. Dermatol Ther 2020, 33, e13666.

19. Burton D.R., Topol E.J.: Toward superhuman SARS-CoV-2 immunity? Nat Med 2021, 27, 5-6.

20. Tartari F., Spadotto A., Zengarini C., Zanoni R., Guglielmo A., Adorno A., et al.: Herpes zoster in COVID-19 patients. Int J Dermatol 2020, 59, 1028-1029.

Received: 10.05 .2021

Accepted: 27.09.2021

Otrzymano: $10.05 .2021 \mathrm{r}$

Zaakceptowano: 27.09.2021 r.

How to cite this article

Krupa O., Małolepsza A., Woźniacka A.: Herpes zoster during the COVID-19 pandemic. Dermatol Rev/Przegl Dermatol 2021, 108, 385-393. DOI: https://doi.org/10.5114/dr.2021.113156 